\title{
Analisis Kualitas Aplikasi Jurnal.Id Menggunakan Metode Webqual 4.0 (Studi Kasus: PT. Wahana Sakti)
}

\author{
Thio Viedya Susanto ${ }^{1}$, Yudiana ${ }^{2}$, Lila Setiyani ${ }^{3}$ \\ ${ }^{2}$ Teknik Informatika, STMIK Rosma, Karawang \\ ${ }^{1,3}$ Sistem Informasi, STMIK Rosma, Karawang \\ E-mail: yudiana@rosma.ac.id
}

\begin{abstract}
The Jorunal.id application is a web-based financial management which is on of the main sources of recording financial transactions at PT. Wahana Sakti. In the Journal.id application there are several data that are managed, including data on sales, costs, purchases, product, ledgers, income statements, cash flow, and many other data contained in the Journal.ud application. The data or information produced is influenced by the quality of the Journal.id application itself. Therefore this study aims to analyse the quality of the Journal.id application using the Webqual 4.0 method at PT. Wahansakti. This research is a descriptive qualitative, research with the daya collection technique used in terviews. The results of the study indicate that the ease of use of users (usability), the quality of information (information quality) and the quality of service interactions (service interaction quality) on the Journal.id application has been very well felt by users.
\end{abstract}

Keywords: Journal.id application, System quality, Webqual

\begin{abstract}
Abstrak
Aplikasi Jurnal.id adalah pengelolaan keuangan berbasis web yang menjadi salah satu sumber utama dalam pencatatan transaksi keuangan PT. Wahana Sakti. Dalam aplikasi Jurnal.id terdapat beberapa data yang dikelola diantaranya data penjualan, biaya, pembelian, produk, buku besar, laporan laba rugi, arus kas, dan masih banyak data lainnya yang terdapat pada aplikasi Jurnal.id. Data atau informasi yang dihasilkan, dipengaruhi oleh kualitas dari aplikasi Jurnal.id itu sendiri. Oleh karena itu penelitian ini bertujuan untuk melakukan analisis kualitas aplikasi Jurnal.id menggunakan metode Webqual 4.0 di PT. Wahana Sakti. Peenelitian ini merupakan penelitian kualitatif deskriptif, dengan teknik pengumpulan data yang digunakan adalah wawancara. Dari hasil penelitian ini memperlihatkan bahwa kemudahan pengguna (usability), kualitas informasi (information quality) dan kualitas layanan interaksi (service interaction quality) pada aplikasi Jurnal.id sudah sangat baik dirasakan oleh pengguna.
\end{abstract}

Kata Kunci: Aplikasi Jurnal.id, Kualitas Sistem, Webqual

\author{
Article History : \\ Received 20, Oktober, 2021 \\ Revised 03, Januari, 2022 \\ Accepted 14, November, 2021 \\ Corresponding Author: \\ Nama Penulis: Yudiana \\ Departemen: Teknik Informatika \\ Instansi: STMIK Rosma \\ Alamat: Jln. Kertabumi No. 62 Karawang Barat \\ Email Penulis: yudiana@ rosma.ac.id
}

\section{Pendahuluan}

Jurnal merupakan buku harian untuk mencatat transaksi keuangan menurut urutan tanggal ke dalam kelompok akun debet dan akun kredit. Dalam akuntansi keuangan terdapat dua jenis buku jurnal, yaitu jurnal umum dan jurnal khusus.

Jurnal umum berasal dari bahasa perancis yaitu (Jour) yang berarti hari. Jurnal umum adalah buku harian atau 
formulir khusus yang digunakan untuk mencatat semua transaksi secara kronologis dan sesuai urutan tanggal. Dengan mencantumkan nama transaksi, kelompok akun, nominal dikolom kredit atau debit.

Sedangkan untuk jurnal khusus adalah jurnal yang digunakan hanya untuk mencatat satu jenis transaksi saja, pada perusahaan dagang jurnal khusus dibagi menjadi empat, yaitu : jurnal khusus pembelian, jurnal khusus penerimaan kas, jurnal khusus penjualan, jurnal khusus pengeluaran kas.

Menurut Kartikahadi (2012:3) dalam [1] mengungkapkan bahwa menjurnal (journalizing) adalah tahap pertama dari suatu proses akuntansi, yaitu membukukan ayat jurnal suatu transaksi atau kejadian dalam wadah pembukuan yang paling dasar, jurnal atau buku harian.

PT.Wahana Sakti adalah perusahaan logistic yang bergerak di bidang Ekspedisi yang memiliki pencatatan transaksi setiap harinya, ke dalam akun debet dan kredit. Akuntansi keuangan pada PT.Wahana Sakti dilakukan dengan melakukan pendataan seperti biaya, penjualan, dan pendapatan. Proses tersebut, dilakukan untuk mengetahui pengeluaran dan pemasukan setiap bulannya. saat ini PT.Wahana Sakti sudah memakai aplikasi Jurnal.id berbasis web namun ada sebagian staff di PT.Wahana Sakti belum teliti saat penginputan data, sehingga masih banyak kesalahan saat mendata suatu laporan penjualan di dalam jurnal.id dan membuat staff accounting tersebut sulit untuk membuat laporan keuangan setiap bulannya.

Berdasarkan uraian masalah yang diatas, maka peneliti tertarik untuk melakukan penelitian terhadap PT.Wahana Sakti dalam menggunakan aplikasi Jurnal.id. Penelitian ini di harapkan untuk mengetahui faktorfaktor yang mempengaruhi kualitas aplikasi Jurnal.id pada PT.Wahana Sakti.

Beberapa penelitian terdahulu seperti yang dikemukakan oleh Hartini mengungkapkan bahwa untuk menganalisis, mengukur kualitas aplikasi berbasis web dapat menggunakan kerangka webqual, [2]. Hal ini juga diperkuat oleh NQ Nada, S Wibowo yang menganalisis pengukuran kualitas layanan sistem informasi akademik menggunakan metode webqual 4.0 yang bertujuan untuk mengetahui tingkat kepuasan pengguna dalam kualitas website sistem akademik universitas dengan menggunakan webqual 4.0 [3]. Iman Sanjaya juga mengungkapkan bahwa pengukuran kualitas layanan website kementrian info dapat diukur menggunakan metode webqual 4.0, sehingga menghasilkan pengukuran tingkat kepuasan pengguna, [4]. Sejalan dengan Iman, Widya juga melakukan analisis pengaruh kualitas website terhadap keputusan pembelian pada web E-Commerce, dalam penelitian tersebut Widya menggunakan verifikasi untuk mengetahui hubungan antara dua variable untuk mengetahui pengaruh kepuasan pengguna web tersebut, [5]. Rizka Amalia Kurniawati dalam penelitiannya juga melakukan analisis kualitas web mister aladin menggunakan webqual, dalam penelitiannya Rizkia melakukan evaluasi untuk menilai apa yang dapat mempengaruhi pelanggan dalam mengakses mister aladin, sehingga didapat hasil pengukuran kualitas layanan dari web tersebut [6].

\section{Tinjauan Pustaka}

\subsection{Aplikasi Jurnal.Id}

Aplikasi Jurnal.id atau Jurnal by Mekari adalah poinieer software akuntansi berbasis cloud di Indonesia yang telah dipercaya oleh lebih dari 20.000 bisnis di Tanah Air. Tampilan aplikasi yang modern dan mudah digunakan oleh siapa pun termasuk untuk akuntan pemula. Sangat membantu dalam menjalankan proses operasonal bisnis dan akuntansi dengan mudah namun tetap detail dan akurat. Jurnal.id memiliki sistem yang 
setara dengan Bank, Jurnal memastikan keamanan data pelanggan sesuai dengan ISO/IEC 27001.

\subsection{Kualitas Sistem}

Amalia \& Pratomo (2016) yang dikutip oleh [7] Kualitas sistem informasi yang digunakan dalam perusahaan, berkaitan dengan sistem informasi yang diterapkan sesuai dengan kebutuhan dan kemampuan pemakai sehingga dapat digunakan untuk mengolah data menjadi suatu informasi yang berkualitas dan berguna bagi pemakai informasi tersebut. Menurut [8] Kualitas sistem dapat digunakan sebagai acuan terhadap sistem yang dimiliki oleh sebuah perusahaan yang dapat digunakan untuk mengatur kualitas pelayanan barang dan jasa. Kualitas sistem informasi digunakan dalam perusahaan, berkaitan dengan sistem informasi yang diterapkan oleh perusahaan sesuai kebutuhan dan kemampuan pemakai sehingga dapat berkolaborasi untuk mengolah data akuntansi menjadi suatu informasi yang berkualitas dan berguna bagi pemakai informasi tersebut. Hal ini diperkuat oleh Davis (1989) yang dikutip oleh [9] kualitas sistem informasi sebagai perceived ease of use yang merupakan tingkat seberapa besar teknologi komputer dirasakan relative mudah untuk dipahami dan digunakan. Kualitas sistem informasi memperliatkan jika pengguna sistem informasi merasa bhawa menggunakan sistem tersebut mudah, pengguna tidak memerlukan effort banyak untuk menggunakannya, sehingga mereka akan lebih banyak waktu untuk mengerjakan hal lain yang kemungkinan akan meningkatkan kinerja mereka secara keseluruhan. Riza Wahyudi juga mengungkapkan kualitas sistem berkualitas dari kombinasi hardware dan software dalam sistem informasi. Fokusnya adalah performa dari sistem itu sendiri, yaitu meruku pada seberapa baik kemampuan perangkat keras, perangkat lunak, kebijakan, prosedur dari sistem informasi dapat menyediakan informasi kebutuhan pengguna [10]

\subsection{Webqual}

Menurut Fauziah dan Wulandari (2017) dalam [8] menjelaskan bahawa metode ini terdiri dari 3 variabel dalam menentukan kualitas website yaitu Usability, Information qualitity dan Service interaction quality. Ketiga metode tersebut dapat memberikan informasi yang akurat dan memberian penilaian terhadap kelayakan website. Sedangkan menurut [4] Webqual merupakan salah satu teknik pengukuran kualitas website berdasarkan persepsi pengguna akhir. Metode Webqual 4.0 diperoleh dari pengembangan webqual versi 1 sampai 3 dan juga disesuaikan dan dikembangkan dari Serverqual.

Menurut Yoga Pratama terdapat beberapa versi dari model Webqual dimana setiap versi digunakan dalam penelitian yang berbeda yang disesuaikan dengan populasi dan kebutuhan penelitian yaitu : Webqual 1.0, terdiri atas 4 variabel yaitu Usefullness, Easy of use, Entertaiment, dan Interaction. Webqual versi pertama ini kuat dalam dimensi kualitas informasi, tetapi lemah dalam service interaction. Webqual 2.0 terbagi dalam 3 area yang berbeda yaitu Quality of website, Quality of information, dan Quality of service interaction. Pada Webqual 2.0 dikembangkan aspek interaksi dengan mengadopsi kualitas pelayanan. Webqual 3.0 diuji mengidentifikasi 3 variabel atas kualitas website e-commerce yatu Usability, Information quality, dan Quality of service interaction. Webqual 4.0 diperoleh dari pengembangan webqual versi 1 sampai 3 dan juga disesuaikan dan dikembangkan dari ServQual. Webqual 4.0 terdiri dari 4 variael yaitu Usablity, Information service quality, dan Overall, [11].

Hal ini diperkuat oleh Barnes \&Vidgen (2002) dalam [12] mengemukakan bahwa dimensi dari mode WebQual 4.0 adalah sebagai berikut. 
Tabel 1. Dimensi WebQual 4.0

\begin{tabular}{|c|c|}
\hline Dimensi & WebQual 4.0 Item \\
\hline Usability & $\begin{array}{l}\text { 1. Kemudahan untuk } \\
\text { dioperasikan. } \\
\text { 2. Interaksi dengan website } \\
\text { jelas dan dapat dimengerti. } \\
\text { 3. Kemudahan untuk navigasi. } \\
\text { 4. Kemudahan menemukan } \\
\text { alamat website. } \\
\text { 5. Tampilan yang atraktif. } \\
\text { 6. Tepat dalam penyusunan } \\
\text { tata letak informasi. } \\
\text { 7. Tampilan sesuai dengan } \\
\text { jenis website pemerintahan. } \\
\text { 8. Adanya penambahan } \\
\text { pengetahuan dari informasi } \\
\text { website. }\end{array}$ \\
\hline $\begin{array}{l}\text { Kual } \\
\text { Infor }\end{array}$ & $\begin{array}{l}\text { 9. Menyediakan informasi } \\
\text { yang cukup jelas. } \\
\text { 10. Menyediakan informasi } \\
\text { yang dapat dipercaya. } \\
\text { 11. Menyediakan informasi } \\
\text { yang up to date. } \\
\text { 12. Menyediakan informasi } \\
\text { yang relevan. } \\
\text { 13. Menyediakan informasi } \\
\text { yang mudah dibaca dan } \\
\text { dipahami. } \\
\text { 14. Menyediakan informasi } \\
\text { yang cukup detail. } \\
\text { 15. Menyediakan informasi } \\
\text { dalam format yang sesuai. }\end{array}$ \\
\hline $\begin{array}{l}\text { Kualitas } \\
\text { layanan } \\
\text { Interaksi }\end{array}$ & $\begin{array}{l}\text { 16. Mempunyai reputasi yang } \\
\text { baik. } \\
\text { 17. Mendapatkan keamanan } \\
\text { untuk melengkapi } \\
\text { transaksi. } \\
\text { 18. Rasa aman dalam } \\
\text { menyampaikan data } \\
\text { pribadi. } \\
\text { 19. Kemudahan untuk menarik } \\
\text { minat dan perhatian. } \\
\text { 20. Adanya suasana komunitas. } \\
\text { 21. Kemudahan untuk } \\
\text { memberikan masukan (feed } \\
\text { back). } \\
\text { 22. Tingkat kepercayaan yang } \\
\text { tinggi atas informasi yang } \\
\text { disampaikan website. }\end{array}$ \\
\hline
\end{tabular}

\subsection{Aplikasi}

Aplikasi adalah program siap pakai yang dapat digunakan untuk menjalankan printah-printah dari pengguna aplikasi tersebut dengan tujuan mendapatkan hasil yang lebih akurat sesuai dengan tujuan pembuatan aplikasi tersebut [8]. Isan Priana dan Leni Fitriani mengatakan aplikasi adalah suatu program siap pakai yang dapat digunakan untuk menjalankan perintah dari pengguna aplikasi dengan tujuan mendapatkan hasil yang lebih akurat sesuai dengan tujuan pembuatan aplikasi tersebut [9]. Menurut Henky (2010) dalam [10] Aplikasi adalah satu unit perangkat lunak yang dibuat untuk melayani kebutuhan akan beberapa aktivitas seperti sistem perniagaan, game, pelayanan masyarakat, periklanan atau semua proses yang hampir dilakukan manusia. Sedangkan menurut Jogiyanto (2012) dalam [11] Aplikasi adalah sekelompok atribut yang terdiri dari beberapa form, report yang disusun sedemikian rupa sehingga dapat mengakses data. Aplikasi merupakan pengolahan data. Jogiyanto menambahkan aplikasi secara umum adalah suatu proses dari cara manual yang ditransformasikan ke komputer dengan membuat sistem atau program agar data diolah lebih berdaya guna secara optimal.

\section{Metode Penelitian}

Metode penelitian yang digunakan dalam penelitian ini adalah kualitatif deskriptif. Penelitian ini menggunakan metode wawancara dengan teknik pengambilan sampel purposive. Pada sampling purposive dilakukan identifikasi awal seseorang atau kasus yang sama dalam kriteria penelitian yaitu para pengguna Jurnal.id di PT. Wahana Sakti. Prosedur pelaksanaan teknik sampling purposive dapat dilakukan dengan wawancara mendalam. Wawancara mendalam dilakukan dengan sejumlah daftar pertanyaan. Wawancara yang dilakukan bersifat informasi dan fleksibel. 


\section{a. Metode Pengumpulan Data}

Metode pengumpulan data yang digunakan dalam penelitian ini adalah metode wawancara. Wawancara dilakukan dengan tidak terstruktur, dilakukan secara bebas, tidak menggunakan pedoman wawancara yang sistematis, pedoman yang dilakukan hanya garis-garis besar permasalahan.

\section{b. Teknik Analisis Data}

Analisis data dalam penelitian ini menggunakan jenis deskriptif kualitatif, sedanglan verifikasi data menggunakan data sekunder dari hasil observasi. Kemudian untuk wawancara pada penelitian ini, peneliti telah melakukan analisis terhadapa jawaba yang diwawancarai. Bila hasil jawaban yang diwawancarai setelah analisis terasa belum memuaskan, maka peneliti melanjutkan wawancara lagi sampai tahap tertentu hingga diperoleh data yang dianggap meyakinkan.

\section{Hasil dan Pembahasan}

\subsection{Hasil Penelitian}

Hasil penelitian diperoleh dari teknik wawancara. Wawancara dilakukan terhadap tiga belas orang narasumber yang dianggap representatice terhadap objek masalah dalam penelitian, Berikut tabel data dari tiga belas narasumber dalam penelitian ini.

Tabel 2. Data Diri Narasumber

\begin{tabular}{|l|l|l|l|l|}
\hline \multicolumn{1}{|c|}{ Nama } & $\begin{array}{c}\text { Jenis } \\
\text { Kelamin }\end{array}$ & Usia & Pendidikan & \multicolumn{1}{|l|}{ Jabatan } \\
\hline Narasumber 1 & Laki-Laki & 41 th & S1 & $\begin{array}{l}\text { Direktur } \\
\text { Operasional }\end{array}$ \\
\hline Narasumber 2 & Laki-Laki & 36 th & S1 & $\begin{array}{l}\text { Manajer } \\
\text { Operasional }\end{array}$ \\
\hline Narasumber 3 & Laki-Laki & 48 th & D3 & $\begin{array}{l}\text { Supervisor } \\
\text { Finance }\end{array}$ \\
\hline Narasumber 4 & Perempuan & 35th & SMK & Cassier \\
\hline Narasumber 5 & Perempuan & 24th & SMK & Administrasi \\
\hline Narasumber 6 & Laki-Laki & 33 th & SMA & $\begin{array}{l}\text { Supervisor } \\
\text { Warehouse }\end{array}$ \\
\hline Narasumber 7 & Laki-Laki & 35th & SMK & $\begin{array}{l}\text { Supervisor } \\
\text { Honda }\end{array}$ \\
\hline Narasumber 8 & Laki-Laki & 35th & SMA & $\begin{array}{l}\text { Supervisor } \\
\text { BLSI }\end{array}$ \\
\hline Narasumber 9 & Laki-Laki & 36th & SMA & $\begin{array}{l}\text { Supervisor } \\
\text { Mitsubishi }\end{array}$ \\
\hline Narasumber 10 & Laki-Laki & 48th & SMA & $\begin{array}{l}\text { Supervisor } \\
\text { DDS1 }\end{array}$ \\
\hline
\end{tabular}

\subsection{Pembahasan Penelitian}

Hasil penelitian berupa kutipan wawancara yang menjelaskan jawaban dari narasumber mengenai kualitas aplikasi Jurnal.id dengan menggunakan metode WebQual 4.0 yang terdiri dari dimensi (kegunaan, kualitas informasi dan kualitas layanan interaksi). Dalam kutipan hasil wawancara tersebut didasarkan pada teori yang dikemukakan oleh Barnes \& Vidgen (2002) dalam bahwa dimensi dari model WebQual 4.0 adalah kegunaan (usability), kualitas informasi (information quality), kualitas layanan interaksi (service interaction quality).

\section{a. Kegunaan (Usability)}

Berikut hasil kutipan wawancara dari tiga belas narasumber mengenai kemudahan pengguna terkait aplikasi Jurnal.id.

Hal ini diungkapkan oleh Narasumber 1 selaku Supervisor Honda mengenai kemudahan untuk pengguna Jurnal.id di PT.Wahana Sakti yang disajikan dalam bentuk kutipan yaitu :

"Sejauh ini mudah untuk digunakan bagi saya pribadi, setiap menu yang ada dijurnal tersebut sangat mudah dimengerti terutama untuk menginput biaya dan penjualan".

Kutipan hasil wawancara dari narasumber diatas didukung oleh pernyataan dari narasumber lain yaitu Narasumber 2 selaku Supervisor Mitsubishi yang juga menjelaskan mengenai kemudahan dalam penggunaan aplikasi Jurnal.id yang dikutip sebagai berikut.

"Kalau menurut saya mudah tidak ada kesulitan, dan untuk aplikasi Jurnal.id sangat membantu dalam penginputan keuangan cuma aplikasi Jurnal.id ini inputannya setiap hari tidak perbulan jadi jika ingin melihat data inputan atau ingin melihat ada kesalahan inputan di bulan lalu harus dicari pertanggal, mungkin dibagian pengecekan nya yang sulit karna tidak global perbulan tapi perhari”.

Disisi lain, aplikasi Jurnal.id sangat mudah digunakan seperti yang diungkap 
oleh Narasumber 3 selaku Supervisor BLSI seperti yang dijelaskan dalam kutipan berikut.

"Bagi saya sangat mudah digunakan".

Sedangkan pendapat dari Narasumber 4 selaku Cassier mengenai kemudahan aplikasi Jurnal.id yang dikutip sebagai berikut.

"Sangat mudah digunakan bagi saya".

Pendapat serupa yang dikemukakan oleh Narasumber 5 selaku Administrasi menyatakan bahwa Jurnal.id mudah untuk digunakan dalam penginputan data transaksi keuangan seperti yang ada dikutipan wawancara sebagai berikut.

"Aplikasi Jurnal.id sangat mudah digunakan dan cukup dimengerti".

Pendapat lain mengenai kemudahan Jurnal.id diungkapkan oleh Narasumber 6 selaku SPV.Warehouse yang dikutip sebagai berikut.

"Bagi saya sangat mudah digunakan".

Hal serupa diungkapkan oleh Narasumber 7 selaku Supervisor Finance mengenai kemudahan dalam menggunakan aplikasi Jurnal.id yang dikutip dari hasil wawancara sebagai berikut.

"Selama ini Jurnal.id sangat mudah untuk digunakan".

Narasumber 8 selaku Supervisor DDS3 juga mengungkapkan mengenai kemudahan aplikasi Jurnal.id yang dikutip sebagai berikut.

"iya sangat mudah dalam menggunakan jurnal, karena tampilan pada Jurnal.id sangat jelas dan dapat dimengerti".

Narasumber 9 selaku Supervisor DDS2 mengungkapkan hal serupa mengenai kemudahan dalam penggunaan aplikasi Jurnal.id yang dikutip sebagai berikut.

"Bagi saya cukup mudah mba".

Narasumber 10 selaku Supervisor DDS1 mengemukakan kemudahan mengenai penggunaan aplikasi Jurnal.id yang dikutip dari hasil wawancara sebagai berikut.
"Sangat mudah mba karena setiap menu yang terdapat di Jurnal.id mudah dimengerti".

Narasumber 11 selaku Supervisor Kurere menjelaskan mengenai kemudahan aplikasi Jurnal.id yang dikutip sebagai berikut.

"Bagi saya selama ini Jurnal.id cukup mudah untuk penginputan baik penjualan maupun biaya".

Dari beberapa pendapat diatas diperkuat oleh Narasumber 12 selaku Manajer Operasional yang menjelaskan mengenai kemudahan dalam penggunaan Jurnal.id yang dikutip sebagai berikut.

"Jurnal.id sendiri sangat mudah digunakan, dan untuk pengguna baru pun mudah untuk mengerti karena setiap menu yang terdapat di Jurnal tersebut mudah untuk dipahami, termasuk dalam penginputan yang ada di dalam Jurnal".

Hal ini lebih diperkuat lagi oleh Narasumber 13 selaku Direktur di PT.Wahana Sakti mengenai kemudahan penggunaan Jurnal.id yang dikutip sebagai berikut.

"mudah sih, cukup menolong".

Dari tiga belas narasumber diatas mengenai kemudahan dalam penggunaan aplikasi Jurnal.id di PT.Wahana Sakti dapat disimpulkan bahwa Jurnal.id sangat mudah digunakan, dan mudah dipahami dari setiap tampilan yang terdapat pada aplikasi Jurnal.id.

\section{b. Kualitas Informasi (Information Quality)}

Berikut adalah kutipan hasil wawancara mengenai kualitas informasi Pernyataan kutipan dari Narasumber 1 mengenai informasi yang dibutuhkan disajikan sebagai berikut.

"Bagi saya sudah cukup dan sudah lengkap, karena informasi sudah ada semua didalam Jurnal.id. Di Jurnal.id tidak hanya untuk input penjualan dan biaya saja, tapi ada kas dan bank yang bisa kita cek”. 
Pendapat yang sama dikemukakan oleh Narasumber 2 yang dinyatakan dalam kutipan sebagai berikut.

"Iya menyediakan dan bagus jadi bisa terlihat semua pengeluaran dan pemasukan sangat jelas".

Begitu pula dengan pernyataan dari Narasumber 3 yang diutarakan dalam kutipan berikut ini.

"Kalau saya cukup menyediakan khususnya untuk transaksi keuangan”.

Narasumber 4 menyatakan pendapat mengenai kualitas informasi yang dibutuhkan dengan kutipan sebagai berikut.

"Menurut saya sangat menyediakan, karena semua data komplit jadi sangat mudah digunakan juga".

Narasumber 5 menyatakan hal yang sama mengenai kualitas informasi yang dibutuhkan dengan kutipan sebagai berikut.

"Saat ini sih sangat menyediakan ya, karena setiap informasi yang ada didalam Jurnal.id sendiri sangat lengkap".

Begitu pula dengan Narasumber 6 yang menyatakan dalam kutipan berikut ini.

"Bagi saya sangat menyediakan informasi yang dibutuhkan".

Adapun pernyataan lain mengenai penyediaan informasi yang up to date. Hal ini diungkapkan juga oleh Narasumber 7 yang diutarakan dalam kutipan yang berbunyi.

"Untuk informasi jurnal sendiri sering memberikan informasi yang up to date karena Jurnal menyediakan messenger untuk mendapatkan informasi terbaru”.

Narasumber 8 menyatakan hal yang sama dalam kutipan sebagai berikut.

"Iya mba, karena Jurnal menyediakan pesan untuk memberikan informasi terbaru”.

Narasumber 9 mengemukakan pendapat mengenai penyediaan informasi yang up to date yang dibutuhkan dalam kutipan berikut.

"Kalau untuk informasi yang up to date saya kurang tau mba karena saya tidak pernah membaca notif dari pesan yang terdapat di Jurnal, sepertinya sih sering ada informasi terbaru kerena sering ada pesan tapi tidak pernah saya buka mba. Jadi saya kurang tau informasi yang up to date nya tentang apa".

Narasumber 10 selaku Supervisor DDS1 juga mengungkapkan hal yang sama mengenai kualitas informasi yang dibutuhkan dalam kutipan sebagai berikut.

"Sering mba, kadang ada pesan dari customer servicenya untuk menginformasikan bahwa Jurnal ada pembaharuan sistem".

Narasumber 11 menyatakan hal serupa dalam kutipan yang berbunyi.

"Jurnal.id sih sering memberikan informasi yang up to date ya mba, salah satunya tampilan yang ada dijurnal awalnya tidak ada menu jurnal pay, sekarang sudah ada dan itu pun ada informasinya di dalam pesan yang ada dijurnal informasinya bahwa jurnal ada penambahan menu".

Narasumber 12 mengutarakan hal yang sama dalam kutipan sebagai berikut.

"Iya memberikan informasi yang up to date kok, salah satunya jurnal memberikan informasi bahwa akun jurnal lama telah berganti menjadi mekari account dan tampilan menu yang ada di jurnal semakin banyak dan lengkap".

Sedangkan Narasumber 13 selaku Manajer di PT.Wahana Sakti yang menyatakan mengenai tentang penyediaan informasi yang detail dan tepat dalam kutipan sebagai berikut

"Bisa dibilang detail dan tepat, tapi sayangnya mereka tidak bisa custom dengan kemauan kita. Jadi contohnya saya mau ada beberapa bagian saya mau custom mereka tidak bisa, itu saja sih kekurangannya".

Berdasarkan semua kutipan jawaban narasumber diatas, maka dapat disimpulkan bahwa kualitas informasi pada aplikasi Jurnal.id menyediakan informasi yang dibutuhkan, dan Jurnal.id sering memberikan informasi yang up to date melalui via chat online, sedangkan untuk menyediakan informasi yang detail dan tepat masih terdapat kekurangan pada Jurnal.id

Jurnal Interkom: Jurnal Publikasi Ilmiah Bidang Teknologi Informasi dan Komunikasi

Volume 16 Nomor 04 Bulan Januari - Tahun 2022 
yaitu pengguna atau customer tidak bisa meminta tampilan yang ada didalam aplikasi Jurnal sesuai keinginan.

\section{c. Kualitas Layanan Interaksi (Service Interaction Quality)}

Berikut adalah kutipan hasil wawancara mengenai kualitas layanan interaksi pada Aplikasi Jurnal.id :

Kutipan jawaban dari Narasumber 1 sebagai berikut.

"Cukup baik sih ya, karena customer service pada Jurnal.id mempunyai kualitas layanan yang cukup baik. Jadi kalau ada masalah pada Jurnal customer servicenya langsung memberi tahu lewat chat".

Kutipan jawaban dari Narasumber 2 sebagai berikut.

"Untuk kualitas layanan nya cukup baik ya, karena ketika ada masalah atau informasi baru mengenai jurnal ada pemberitahuannya".

Kutipan jawaban dari Narasumber 3 sebagai berikut.

"Iya cukup baik untuk kualitas layanannya, soal nya di Jurnal menyediakan via chat online untuk memberikan informasi terbaru mengenai jurnal tersebut".

Kutipan jawaban dari Narasumber 4 sebagai berikut.

"Cukup baik sih mba untuk kualitas layanan nya, terdapat via chat online yang bisa mendapatkan informasi terbaru mengenai Jurnal seperti pembaharuan sistem".

Kutipan jawaban dari Narasumber 5 sebagai berikut.

"Untuk kualitas layanannya sih cukup baik. Jika ada informasi baru yang berkaitan dengan Jurnal sering mengirimkan notifikasi via chat online yang ada di aplikasi Jurnalnya".

Selain itu terdapat pernyataan lain mengenai keamanan dalam menyampaikan data pribadi.

Kutipan jawaban dari Narasumber 6 sebagai berikut.
"Selama ini sih masih aman, karena selama saya memakai Jurnal password saat pertama kali login tidak pernah di hack”.

Kutipan jawaban dari Narasumber 7 sebagai berikut.

"Untuk data pribadi masih aman dalam penggunaan Jurnal, karena username dan password belum pernah ada yang retas".

Kutipan jawaban dari Narasumber 8 sebagai berikut.

"Selama ini masih aman untuk data pribadi, karena password maupun username selama ini masih tetap terjaga keamanannya".

Kutipan jawaban dari Narasumber 9 sebagai berikut.

"Untuk data pribadi sih masih aman belum pernah mengalami di hack untuk username maupun password".

Kutipan jawaban dari Narasumber 10 sebagai berikut.

"Selama ini masih aman sih, karena password dan username belum pernah di pakai sama orang tanpa pengetahuan kita".

Kutipan jawaban dari Narasumber 11 sebagai berikut.

"Iya selama ini sih masih memberikan rasa aman untuk data pribadi, karena saya belum pernah mengalami password atau username di hack".

Kutipan jawaban dari Narasumber 12 sebagai berikut.

"Selama ini Jurnal.id masih memberikan rasa aman dalam menyampaikan data pribadi, salah satunya untuk username dan password belum pernah ada yang mengalami di hack, walaupun kita sering membuka jurnal di komputer orang lain".

Kutipan jawaban dari Narasumber 13 sebagai berikut.

"Untuk data pribadi selama ini masih aman, salah satunya username dan password untuk login walaupun pengguna membuka jurnal di komputer lain atau di website lain username dan password belum pernah mengalami di hack". 
Berdasarkan pernyataan dari pada narasumber diatas, maka dapat diketahui bahwa kualitas layanan pada Jurnal.id mempunya reputasi yang baik dalam kualitas layanan, dna data pribadi pengguna masih terjaga dengan aman oleh Jurnal.id sehingga ketika ingin membuka jurnal di komputer lain password dan username masih tetap aman.

\section{Kesimpulan}

Berdasarkan hasil analisis data dan pembahasan pada bab sebelumnya, maka dapat diambil kesimpulan sebagai berikut:

a. Kegunaan (Usability), kesimpulan yang dapat diambil terdapat indikator yang sesuai dengan variabel kegunaan (Usability) yaitu "Kemudahan untuk dioperasikan" Jurnal.id adalah aplikasi berbasis website yang sangat mudah digunakan oleh pengguna, tampilan pada jurnal.id memberikan kemudahan untuk dioperasikan pada setiap pengguna di PT.Wahana Sakti dengan website yang jelas dan dapat dimengerti.

b. Kualitas Informasi (Information Quality), kesimpulan yang dapat diambil terdapat indikator yang sesuai dengan variabel kualitas informasi (information quality) yaitu "menyediakan informasi yang up to date" Jurnal.id memberikan informasi yang up to date melalui via chat online yang terdapat dalam aplikasi Jurnal.id berbasis web. Namun untuk indikator "menyediakan informasi yang detail dan tepat" masih terdapat kekurangan pada Jurnal.id yaitu pengguna tidak bisa meminta tampilan yang ada didalam aplikasi Jurnal.id sesuai keinginan.

c. Kualitas Layanan Interaksi (Service Interaction Quality), kesimpulan yang dapat diambil terdapat dua indikator yang sesuai dengan variabel kualitas layanan interaksi (service interaction quality) yaitu "kualitas layanan yang mempunyai reputasi yang baik" dan "adanya rasa aman dalam menyampaikan data pribadi". Dapat diketahui bahwa kualitas layanan pada Jurnal.id mempunyai reputasi yang baik, respon dari setiap customer service jurnal sangat cepat dan tanggap, serta kualitas layanan Jurnal.id bisa memberikan rasa aman untuk pengguna menyampaikan data pribadi.

\section{Daftar Pustaka}

[1] R. \& R. Novita, "Pengembangan Modul Akuntansi Berorientasi Kontekstual Pada Materi Mencatat Transaksi Ke Jurnal Umum Perusahaan Jasa," J. Umum Perusah. Jasa, pp. 1-7, 2014.

[2] S. Hartini, "Metode Webqual pada Analisis Layanan Website PPBD Online Kabupaten Bekasi," Inf. Syst. Educ. Prof., vol. 1, no. 1, pp. 35-41, 2016.

[3] N. Qotrun and S. Wibowo, "Pengukuran Kualitas Layanan Sistem Informasi Akademik," $J$. Inform. Upgris, vol. 1, no. 1, pp. 122 131, 2016.

[4] I. Sanjaya, "Pengukuran Kualitas Layanan Website Kementerian Kominfo dengan menggunakan Webqual 4.0," J. Penelit. IPTEKKOM, vol. 14, no. 1, pp. 1-14, 2012.

[5] W. Sastika, "Analisis Pengaruh Kualitas Website (WebQual 4.0) Terhadap Keputusan Pembelian pada Website e-commerce Traveloka," Sentika, vol. 2016, no. Sentika, pp. 18-19, 2016.

[6] R. A. Kurniawati, A. Kusyanti, and Y. T. Mursityo, "Analisis Pengaruh Kualitas Website Terhadap Kepuasan Pelanggan Mister Aladin Dengan Menggunakan Webqual 4.0," $J$. Pengemb. Teknol. Inf. dan Ilmu Komput., 2018.

[7] B. A. R. Tulodo and A. Solichin, 
"Analisis Pengaruh Kualitas Sistem, Kualitas Informasi Dan Perceived Usefulnes Terhadap Kepuasan Pengguna Aplikasi Care Dalam Upaya Peningkatan Kinerja Karyawan (Studi Kasus PT. Malacca Trust Wuwungan Insurance, Tbk.)," J. Ris. Manaj. Sains Indones., vol. 10, no. 1, pp. 27-43, 2019, doi: doi.org/10.21009/JRMSI.010.1.02.

[8] L. Setiyani, J. Wagiar, E. Tjandra, S. Tinggi, and M. Informatika, "WILAYAH BIDANG PENDIDIKAN KECAMATAN KUTAWALUYA MENGGUNAKAN MODEL WEBQUAL 4 . 0," vol. 15 , no. 2 , pp. 12-20, 2020.

[9] F. A. Pamungkas, "Pengaruh Kualitas Sistem Informasi, Kualitas Informasi, Dan Perceived Usefulness Terhadap Kepuasan Pengguna Akhir Software
Akuntansi," vol. 1, p. 21, 2017.

[10] R. Wahyudi and E. S. A. Riyadi, "PENGARUH

KUALITAS

SISTEM, INFORMASI DAN

PELAYANAN

TERHADAP

SIAKAD

MAHASISWA

KEPUASAN

Mahasiswa Program Sarjana Fakultas

Ilmu Administrasi, Universitas Brawijaya)," J. Adm. Bisnis S1 Univ. Brawijaya, vol. 23, no. 2, pp. 28-39, 2015.

[11] A. P. Kurniawan, "Pengukuran Kualitas Website Universitas Telkom Menggunakan Metode WebQual 4.0," Inst. Teknol. Telkom Purwokerto, pp. 1-5, 2018.

[12] C. Irawan, "Evaluasi Kualitas Website Pemerintah Daerah Dengan Menggunakan Webqual (Studi Kasus Pada Kabupaten Ogan Ilir)," Sriwij. J. Inf. Syst., vol. 4, no. 2, 2012. 